\title{
Karakterisasi Pengeringan Bawang Merah (Allium cepa L.) Menggunakan Tray Dryer
}

\author{
Characterization of Drying Shallots (Allium cepa L.) Using Tray Dryer \\ Rintis Manfaati ${ }^{\left({ }^{*}\right)}$, Hibah Baskoro ${ }^{1}$, Muhammad Muhlis Rifai ${ }^{1)}$ \\ ${ }^{1)}$ Politeknik Negeri Bandung, D3 Teknik Kimia, Indonesia \\ *email: rintis.manfaati@polban.ac.id
}

Received: 18/10/20; Revised: 18/11/20; Accepted: 26/11/20

\begin{abstract}
Abstrak
Pengeringan bawang merah (Allium cepa L.) menggunakan tray dryer bertujuan menghasilkan produk sesuai standar bahan kering, tetapi kadar nutrisinya tetap dipertahankan. Tujuan dari penelitian ini adalah mempelajari karakteristik proses pengeringan bawang merah melalui beberapa tinjauan yaitu kadar air bawang merah setelah pengeringan, laju pengeringan konstan (Rc), kadar air bebas kritis $(\mathrm{Xc})$, parameter pengeringan $(\mathrm{k})$, profil kurva laju pengeringan menurun dan nilai difusivitas rata-rata. Pengeringan dilakukan pada bawang merah dengan kadar air awal 82,5\%, dan ketebalan 1-2 mm. Suhu pengeringan divariasi pada rentang $50-70{ }^{\circ} \mathrm{C}$, waktu pengeringan 6 jam dan laju udara pengeringan $2,0 \mathrm{~m} / \mathrm{s}$. Hasil penelitian menunjukkan bahwa suhu optimum pengeringan adalah $70{ }^{\circ} \mathrm{C}$ dengan kadar air bawang merah setelah pengeringan adalah 8,3896\%, nilai Rc yaitu $1,2968 \mathrm{~kg} / \mathrm{jam} \cdot \mathrm{m}^{2}$, nilai Xc yaitu 2,3044 kg air/kg bahan kering dan nilai k adalah 0,0173 menit $^{-1}$. Profil perpindahan air terikat dalam bawang merah terjadi secara difusi dengan nilai difusivitas ratarata $\left(D_{\mathrm{L}}\right)$ adalah $1,5556.10^{-10} \mathrm{~m}^{2} /$ detik.
\end{abstract}

Kata kunci: bawang merah; difusivitas; kadar air; laju pengeringan; tray dryer

\begin{abstract}
Drying shallots using a tray dryer aims to produce dry material according to standars but the nutritional content is maintained. The purpose of this study was to know the characteristics of the shallot drying process through several reviews, namely the moisture content of shallots after drying, constant drying rate $(R c)$, critical free water content $(X c)$, drying parameter $(k)$, curve of drying falling rate profile and the average diffusivity $\left(D_{L}\right)$. Drying is carried out on the shallots with initial moisture content of $82.5 \%$, and a thickness 1-2 mm. Drying temperatures was varied in the range of $50-70{ }^{\circ} \mathrm{C}$, drying time of 6 hours and drying air rate of $2.0 \mathrm{~m} / \mathrm{s}$. The results showed that the optimum temperature for drying shallots using a Tray Dryer was $70{ }^{\circ} \mathrm{C}$ with the moisture content of shallots after drying was $8.3896 \%$, The Rc value was $1.2968 \mathrm{~kg} / \mathrm{hour} . \mathrm{m}^{2}$, the Xc value was $2.3044 \mathrm{~kg}$ of water $/ \mathrm{kg}$ of material dry and the $k$ value was 0.0173 minute ${ }^{-1}$. The transfer of bound water in shallots occurs diffusion where the average diffusivity $\left(D_{L}\right)$ was $1.5556 .10^{-10} \mathrm{~m}^{2} / \mathrm{s}$.
\end{abstract}

Keywords: diffusivity; drying rate; moisture content; shallots; tray dryer. 


\section{PENDAHULUAN}

Total produksi nasional bawang merah pada tahun 2018 mencapai 1,503 juta ton. Produksi bawang merah nasional tahun 2018 tumbuh sebesar 2,26 persen dibandingkan tahun 2017. Enam provinsi penghasil bawang merah utama adalah Jawa Tengah, Jawa Timur, Nusa Tenggara Barat, Jawa Barat, Sumatera Barat dan Sulawesi Selatan (Adhiwibowo \& Ramadhanty, 2018). Peningkatan produksi bawang merah setiap tahun, menyebabkan stok bawang merah melimpah sehingga harga bawang merah akan turun.

Bawang merah digunakan sebagai penyedap masakan di beberapa negara. Bawang merah memiliki kandungan bahan-bahan kimia yang bermanfaat seperti serat alami, berbagai vitamin, asam organik, senyawa-senyawa phenolic dan antioksidan (Mitra $d k k$.,2012). Setiap 100 gram bawang merah mengandung 84,18 gram air, 0,93 gram serat dan 2,43 gram protein (Rodrigues $d k k ., 2003$ ).

Pengeringan bawang merah sampai kadar air kurang dari $10 \%$ akan mencegah pertumbuhan mikroorganisme sehingga dapat memperpanjang umur penyimpanan dan meningkatkan nilai tambah dari produk tersebut. Pengeringan bawang merah secara konveksi, dengan memanfaatkan panas matahari umum dilakukan. Pengeringan dengan cara ini dapat menghemat biaya untuk energi pengeringan tetapi membutuhkan waktu yang lama dan tergantung pada kondisi cuaca. Pada musim hujan, kandungan uap air/kelembaban cukup tinggi maka proses pengeringan menggunakan sinar matahari tidak menghasilkan proses pengeringan yang sempurna karena adanya karakter sorption isotherm (Sasongko dkk., 2020).

Salah satu metode pengolahan dan pengawetan bawang merah adalah melalui pengeringan menggunakan tray dryer. Proses pengeringan menggunakan tray dryer termasuk dalam jenis pengeringan langsung, dimana media pengering (udara panas) berkontak langsung dengan bahan yang akan dikeringkan. Bahan yang akan dikeringkan harus berbentuk lembaran yang dihamparkan diatas tray agar produk mengering secara merata.

Proses pengeringan melibatkan dua proses perpindahan yaitu perpindahan panas yang terjadi dari media pengering ke bahan yang akan dikeringkan, dan perpindahan massa yang terjadi dari bahan yang akan dikeringkan ke media pengering. Proses pengeringan dimulai saat udara panas yang mengalir melintasi permukaan lembaran padatan. Perpindahan panas terjadi secara konduksi melalui tray yang panas atau secara radiasi melalui permukaan bahan yang dipanaskan (Misha $d k k ., 2013)$. Udara panas yang mengalir akan melepaskan sebagian panasnya sehingga terjadi proses penguapan/perpindahan massa air dari bahan yang dikeringkan ke udara tersebut sampai mencapai kondisi kesetimbangan.

Pengeringan bawang merah menggunakan tray dryer harus menghasilkan produk sesuai standar bahan kering, tetapi kadar nutrisinya tetap dipertahankan. Pengeringan pada suhu tinggi dapat menurunkan kandungan vitamin $\mathrm{C}$, merubah warna dan mengurangi kandungan nutrisi lain (Mota $d k k$., 2010). Penelitian pengeringan menggunakan tray dryer ataupun peralatan pengeringan lain seperti fluidized drying untuk bawang merah dan produk pangan lain seperti parsley, kopi, jagung dan padi selalu dilakukan pada suhu pengeringan kurang dari $70 \quad{ }^{\circ} \mathrm{C}$ (Sasongko dkk., 2020; Hancioglu dkk., 2010; Pradana $d k k ., 2019$; Djaeni \& Perdanianti, 2019; Djaeni $d k k$., 
2011: Santoso $d k k .$, 2018; Nugraha $d k k$, 2011; Djaeni $d k k ., 2013)$.

Setiap bahan padat yang dikeringkan memiliki karakteristik pengeringan yang berbeda-beda. Karakteristik pengeringan tersebut adalah kadar air produk setelah pengeringan, laju pengeringan konstan (Rc) dan kadar air bebas kritis (Xc). Laju pengeringan berkaitan dengan proses pengeringan yang terdiri dari dua periode utama yaitu, periode pengeringan dengan laju pengeringan konstan (Constant Rate Periode) dan periode pengeringan dengan laju pengeringan menurun (Falling Rate Periode). Kedua periode ini dibatasi oleh kadar air bebas kritis (Xc) (Geankoplis, 1993).

Djaeni \& Perdanianti (2019) telah melakukan penelitian pengeringan bawang merah yang lebih berkembang. Tray dryer dioperasikan secara batch dengan menggunakan udara panas yang telah didehumidifikasi menggunakan tiga jenis dessicant yaitu karbon aktif, silika gel dan zeolit. Dessicant digunakan untuk menyerap uap air dalam udara pengering, sehingga diharapkan dapat mengurangi energi untuk pengeringan dan mempersingkat waktu pengeringan. Tiga model kinetika pengeringan Lapis Tipis digunakan, sehingga dihasilkan parameter pengeringan $\mathrm{k} \quad\left(\right.$ menit $\left.^{-1}\right)$. Kelemahan penggunaan dessicant dalam proses pengeringan adalah diperlukan energi yang cukup tinggi untuk meregenerasi dessicant yang jenuh. Untuk melepaskan $1 \mathrm{~kg}$ air dari dessicant zeolit tipe $13 \mathrm{X}$ yang jenuh dibutuhkan energi sebesar 3200 kJ (Djaeni $d k k ., 2013)$.

Penelitian pengeringan bawang merah tanpa mengaplikasikan dessicant masih tetap terbuka untuk dilakukan, agar proses pengeringan dapat dipahami lebih mendalam melalui karakteristik pengeringan lain yaitu kadar air bawang merah setelah pengeringan, laju pengeringan konstan (Rc), kadar air bebas kritis (Xc), parameter pengeringan (k), dan profil kurva laju pengeringan menurun serta nilai difusivitas rata-rata $\left(D_{L}\right)$.

\section{METODE PENELITIAN}

Perlakuan awal terhadap bawang merah adalah pengupasan dan pengirisan dengan ketebalan 1-2 mm. Bawang merah yang telah diiris disusun dalam tray berlubang yang memiliki luas 20x20 cm. Laju alir udara pengering adalah $2,0 \mathrm{~m} / \mathrm{s}$ dan waktu pengeringan adalah 6 jam. Suhu pengeringan divariasikan pada rentang 50$70{ }^{\circ} \mathrm{C}$. Pengambilan data berupa massa bawang merah dilakukan setiap 10 menit,

Alat yang digunakan adalah Tray Dryer Electronica Veneta yang dilengkapi pemanas berdaya $2,7 \mathrm{~kW}$, tray, anemometer, termometer bola basah dan bola kering, cawan pijar, stop watch, oven, desikator. Skema tray dryer yang digunakan disajikan pada Gambar 1.

Analisis kadar air dilakukan menggunakan metode gravimetri. Prosedur analisis ini adalah dengan mengeringkan bawang merah dalam oven pada suhu 105 ${ }^{\circ} \mathrm{C}$ selama 3 jam sehingga seluruh air yang terdapat dalam bahan menguap dengan ditandai dengan massa bahan yang konstan.

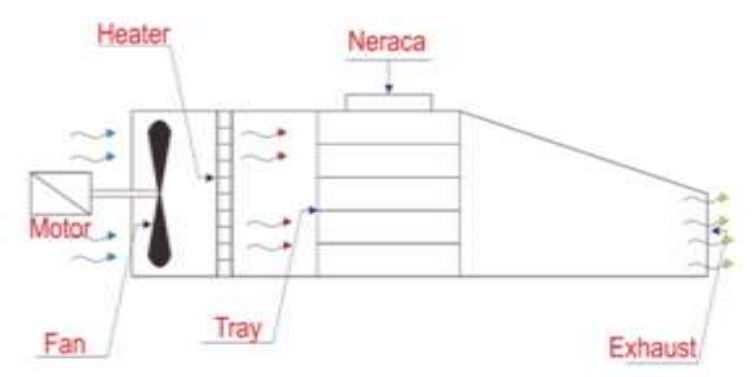

Gambar 1. Skema Tray Dryer 
Laju pengeringan dapat diperoleh dengan persamaan (1) berikut:

$R=-\frac{L s}{A} \times \frac{d X}{d t}$

$\mathrm{R}=$ laju pengeringan $\left(\mathrm{kg} / \mathrm{jam} \cdot \mathrm{m}^{2}\right)$

$\mathrm{Ls}=$ berat kering bahan pada tray $(\mathrm{kg})$

$\mathrm{A}=$ luas permukaan saat pengeringan $\left(\mathrm{m}^{2}\right)$

(Geankoplis, 1993).

Kurva pengeringan dapat pula disajikan dalam bentuk rasio kadar air bahan $\left(\mathrm{M}_{\mathrm{R}}\right)$ terhadap waktu pengeringan (t). Parameter kinetika (k) dapat diperoleh melalui persaman kinetika Pengeringan Newton sebagai berikut:

$$
\begin{aligned}
& M_{R}=e^{-k t} . \\
& M_{R}=\frac{M_{t}}{M_{0}} \ldots
\end{aligned}
$$

$\mathrm{M}_{\mathrm{t}}=$ kadar air saat waktu pengeringan $\mathrm{t}$

$\mathrm{M}_{\mathrm{o}}=$ kadar air awal

$\mathrm{k}=$ parameter pengeringan $\left(\right.$ menit $\left.^{-1}\right)$

(Lewis, 1921)

Nilai difusivitas rata-rata diperoleh dengan menggunakan persamaan berikut:

$D_{L}=\left[\frac{D_{L} t}{x_{1}^{2}}\right]$ theari $\frac{x_{1}^{2}}{t}$

$\mathrm{D}_{\mathrm{L}}=$ difusivitas rata-rata $\left(\mathrm{m}^{2} /\right.$ detik $)$

$\mathrm{t} \quad=$ waktu pengeringan (detik)

$\mathrm{x}_{1}{ }^{2}=$ tebal irisan bahan $(\mathrm{m})$.

(Geankoplis, 1993).

\section{HASIL DAN PEMBAHASAN}

Kadar Air Bawang Merah

Pengaruh suhu terhadap kadar air bawang merah setelah proses pengeringan disajikan pada Gambar 2. Semakin besar suhu pengeringan yang digunakan dalam proses pengeringan maka semakin rendah kadar air produk yang dihasilkan. Pada suhu pengeringan $50-65{ }^{\circ} \mathrm{C}$ kadar air produk yang dihasilkan masih di atas $10 \%$.

Produk dengan kadar air terendah diperoleh pada suhu $70{ }^{\circ} \mathrm{C}$ yaitu $8,3896 \%$.
Semakin tinggi suhu udara pengeringan akan menghasilkan driving force yang yang besar sehingga meningkatkan perpindahan air dari padatan ke udara pengering. Kadar air produk bisa diturunkan lebih rendah dengan cara meningkatkan suhu pengeringan, tetapi dikhawatirkan akan merusak kandungan nutrisi dalam bawang merah. Alternatif lain untuk meningkatkan driving force adalah dengan mengaplikasikan dessicant seperti karbon aktif, silika gel dan zeolit adsorben sehingga dihasilkan udara pengering yang terdehumidifikasi (Djaeni \& Perdanianti, 2019).

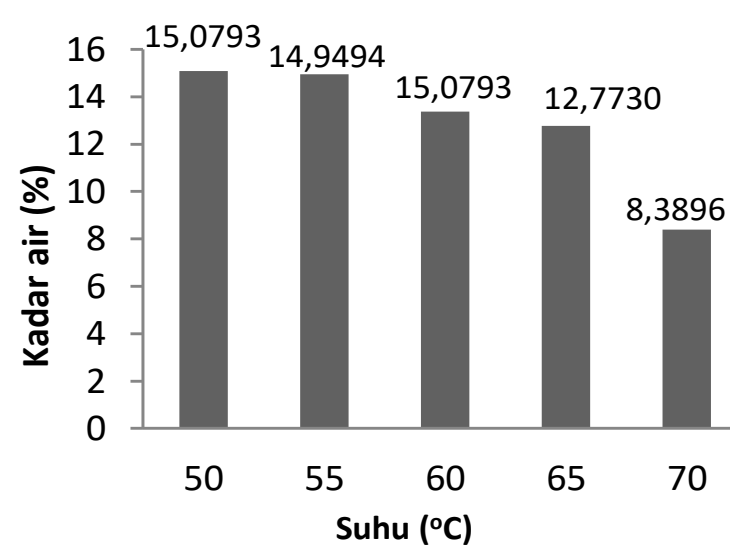

Gambar 2. Kadar Air Bawang Merah setelah Pengeringan pada Berbagai Suhu Pengeringan

\section{Laju Pengeringan}

Kurva laju pengeringan menunjukkan karakteristik pengeringan untuk setiap bahan pada kondisi suhu, kecepatan alir udara pengering, dan tekanan yang spesifik (Traub, 2002). Kurva pengeringan untuk rentang suhu pengeringan $50-70{ }^{\circ} \mathrm{C}$ disajikan pada Gambar 3 sampai dengan Gambar 7 sedangkan rasio kadar air dapat dilihat pada Gambar 8. Kadar air bebas kritis (Xc), laju pengeringan konstan (Rc) dan parameter pengeringan (k) pada berbagai suhu pengeringan disajikan pada Tabel 1. 


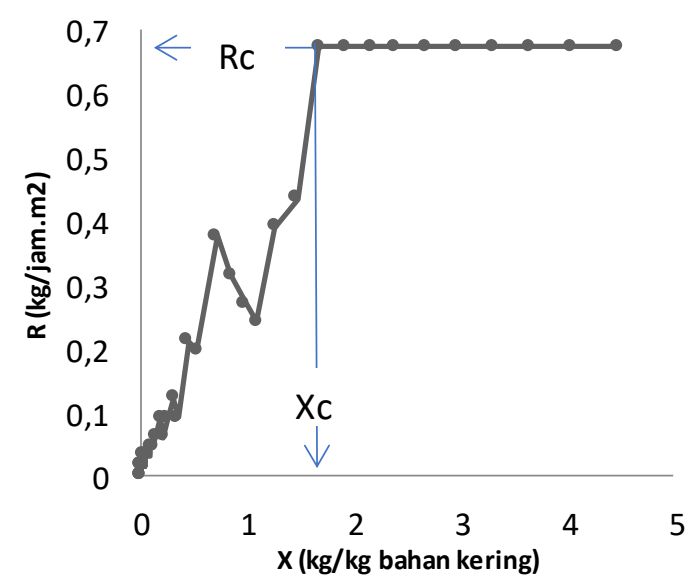

Gambar 3. Laju Pengeringan (R) terhadap Kadar Air Bebas (X) pada Suhu Pengeringan $50{ }^{\circ} \mathrm{C}$

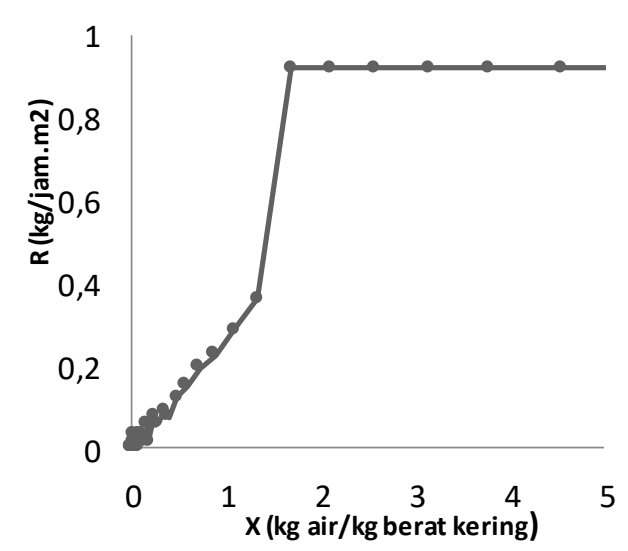

Gambar 5. Laju Pengeringan (R) terhadap Kadar Air Bebas (X) pada Suhu Pengeringan $60^{\circ} \mathrm{C}$

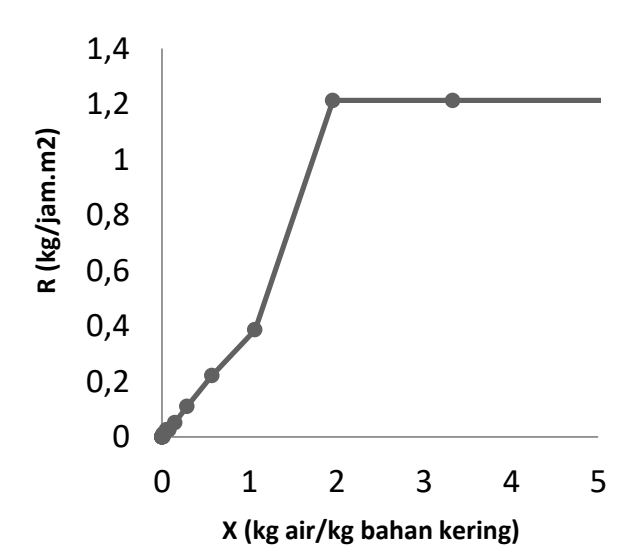

Gambar 7. Laju Pengeringan (R) terhadap Kadar Air Bebas (X) pada Suhu Pengeringan $70{ }^{\circ} \mathrm{C}$.

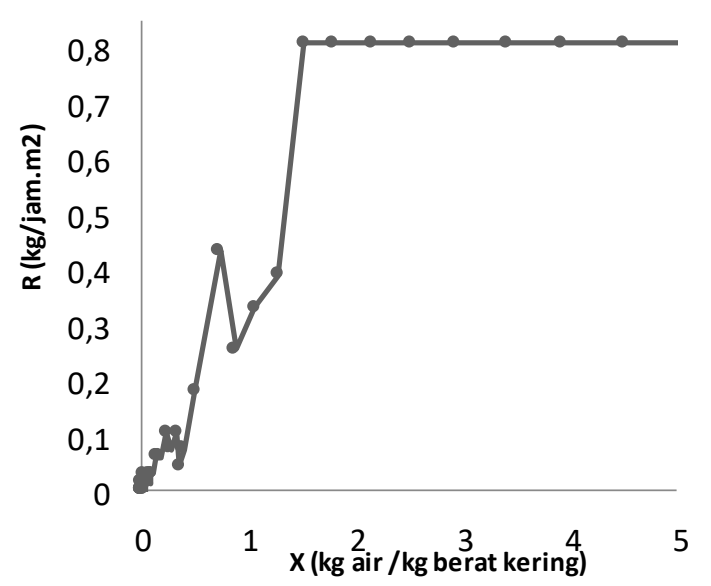

Gambar 4. Laju Pengeringan (R) terhadap Kadar Air Bebas (X) pada Suhu Pengeringan $55^{\circ} \mathrm{C}$

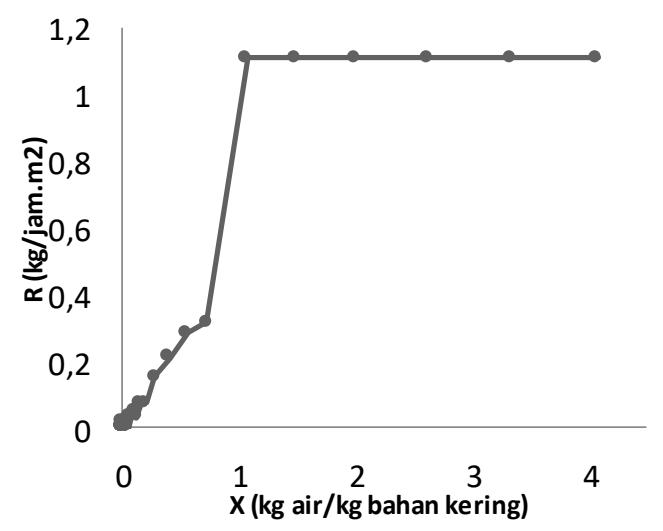

Gambar 6. Laju Pengeringan (R) terhadap Kadar Air Bebas (X) pada Suhu Pengeringan $65^{\circ} \mathrm{C}$.

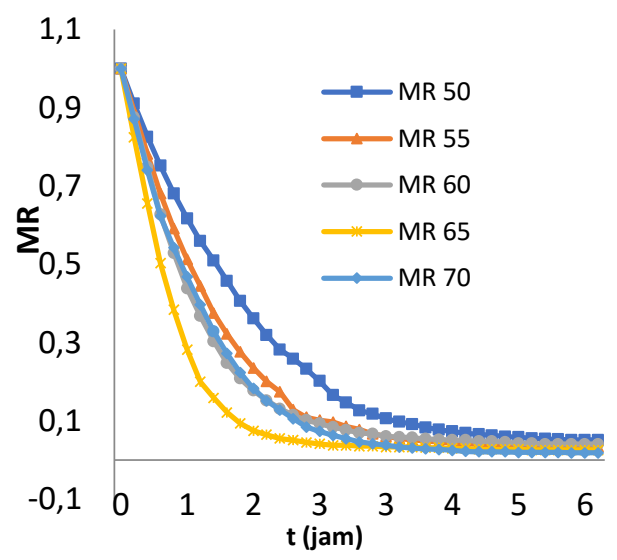

Gambar 8. Rasio Kadar Air bahan (MR) terhadap Waktu Pengeringan pada Berbagai Suhu Pengeringan 
Tabel 1. Kadar Air Bebas Kritis (Xc), Laju Pengeringan Konstan (Rc) dan Parameter Pengeringan (k)

\begin{tabular}{cccc}
\hline $\begin{array}{c}\text { Suhu } \\
\left({ }^{\circ} \mathrm{C}\right)\end{array}$ & $\begin{array}{c}\text { Xc (kg air/kg } \\
\text { bahan kering) }\end{array}$ & $\begin{array}{c}\text { Rc } \\
\left(\mathrm{kg} / \text { jam.m }{ }^{2}\right)\end{array}$ & $\begin{array}{c}\mathrm{k} \\
\left(\text { menit }^{-1}\right)\end{array}$ \\
\hline 50 & 1,6773 & 0,6726 & 0,0104 \\
55 & 1,5152 & 0,8100 & 0,0158 \\
60 & 1,6945 & 0,9178 & 0,0167 \\
65 & 1,0719 & 1,1092 & 0,0229 \\
70 & 2,3044 & 1,2968 & 0,0173 \\
\hline
\end{tabular}

Pada proses pengeringan, air yang teruapkan terdiri dari air tidak terikat dan air terikat. Laju pengeringan tertinggi terjadi pada periode pengeringan konstan. Pada periode pengeringan konstan yang teruapkan adalah air yang tidak terikat yang membentuk lapisan tipis/film air kontinu dipermukaan bahan.

Suhu udara pengering sangat berpengaruh terhadap kecepatan pengeringan, semakin tinggi suhu pengeringan, semakin tinggi pula nilai laju pengeringan konstan (Rc). Tabel 1 menunjukkan bahwa laju pengeringan konstan tertinggi diperoleh pada suhu 70 ${ }^{\circ} \mathrm{C}$ yaitu 1,2968 kg/jam.m ${ }^{2}$. Jika jumlah air tidak terikat pada setiap bahan yang dikeringkan adalah sama, maka dengan laju pengeringan lebih tinggi waktu pengeringan dapat dipersingkat. Waktu pengeringan yang lebih singkat akan menguntungkan secara ekonomis.

Kadar air bebas kritis (Xc) untuk suhu pengeringan $50-60{ }^{\circ} \mathrm{C}$ tidak menunjukkan perbedaan yang berarti, yaitu berada pada rentang 1,5152-1,6945 $\mathrm{kg}$ air/kg bahan kering. Driving force pada suhu pengeringan $50-60{ }^{\circ} \mathrm{C}$ tidak cukup untuk menarik air tidak terikat yang ada di bagian dalam padatan bawang merah untuk keluar ke permukaan dan menguapkannya, sehingga menghasilkan Xc yang relatif sama. Peningkatan cukup berarti terjadi pada suhu pengeringan $70{ }^{\circ} \mathrm{C}$ yaitu sebesar
2,3044 kg air/kg bahan kering. Pada suhu ini air tidak terikat yang terdapat di bagian dalam padatan akan ditarik dan teruapkan dengan sempurna sehingga air yang tertinggal dalam padatan selama periode pengeringan konstan adalah air yang terikat saja. Air yang terikat ini akan diuapkan selama periode laju pengeringan menurun.

Parameter pengeringan (k) yang diperoleh dari persamaan Newton untuk suhu pengeringan $70{ }^{\circ} \mathrm{C}$ adalah 0,0173 menit $^{-1}$. Nilai $\mathrm{k}$ ini lebih kecil dibandingkan dengan nilai $\mathrm{k}$ yang diperoleh pada pengeringan bawang merah suhu $70 \quad{ }^{\circ} \mathrm{C}$ dengan mengaplikasikan dessicant zeolit pada tray dryer yaitu 0,0374015 menit ${ }^{-1}$ (Djaeni \& Perdanianti, 2019). Hal tersebut menunjukkan bahwa pengaplikasian dessicant akan meningkatkan kinerja dari tray dryer.

Profil kurva laju pengeringan menurun dapat menunjukkan pola perpindahan uap air. Perpindahan uap air ini dapat terjadi secara difusi atau melalui kapiler. Difusi uap air terjadi karena adanya perbedaan konsentrasi uap air antara bagian dalam dan bagian permukaan padatan. Perpindahan uap air secara difusi biasanya terjadi pada padatan yang tidak berpori seperti pasta, sabun, gelatin, lem, tepung,kayu, kulit, kertas, tekstil dan berbagai bahan pangan (Geankoplis, 1993). Perpindahan uap air melalui kapiler terjadi karena pada saat air diuapkan akan terbentuk meniskus pada setiap pori. Meniskus menghasilkan tegangan permukaan air menyebabkan terbentuknya capillary forces yang merupakan driving force berpindahnya air melalui pori-pori ke permukaan. Perpindahan uap air melalui kapiler terjadi pada padatan berpori dan berbentuk granular seperti tanah liat, pasir, 
tanah, pigmen dan mineral (Geankoplis, 1993).

Gambar 5, 6 dan 7 menunjukkan bahwa suhu pengeringan yang lebih tinggi yaitu $60-70{ }^{\circ} \mathrm{C}$ menghasilkan kurva laju pengeringan menurun yang lebih stabil dibandingkan dengan suhu pengeringan yang lebih rendah 50 dan $55^{\circ} \mathrm{C}$ (Gambar 3 dan 4). Profil kurva laju pengeringan menurun bawang merah menunjukkan bahwa berpindahnya uap air terjadi secara difusi dengan nilai difusivitas rata-rata (D $\mathrm{D}_{\mathrm{L}}$ adalah $1,5556.10^{10} \mathrm{~m}^{2} /$ detik. Periode laju pengeringan menurun berlangsung mendekati linear hingga kadar air dalam bahan sama dengan kadar air kesetimbangan.

\section{KESIMPULAN}

Hasil penelitian menunjukkan bahwa suhu optimum pengeringan bawang merah menggunakan tray dryer adalah $70{ }^{\circ} \mathrm{C}$ dengan kadar air bawang merah setelah proses pengeringan $8,3896 \%$, nilai laju pengeringan konstan (Rc) 1,2968 $\mathrm{kg} / \mathrm{jam} . \mathrm{m}^{2}$, kadar air bebas kritis (Xc) 2,3044 $\mathrm{kg}$ air/kg bahan kering dan parameter pengeringan (k) 0,0173 menit $^{-1}$. Profil kurva laju pengeringan menurun bawang merah menunjukkan bahwa berpindahnya uap air terikat pada bawang merah terjadi secara difusi dengan nilai difusivitas rata-rata $\left(\mathrm{D}_{\mathrm{L}}\right)$ adalah 1,5556.10${ }^{10} \mathrm{~m}^{2} /$ detik.

\section{DAFTAR RUJUKAN}

Adhiwibowo, K., \& Ramadhanty, A. (2018). Distribusi Perdagangan Komoditas Bawang Merah Indonesia. BPS RI/BPS-Statistics Indonesia. ISBN: 978-602-438-318-3 No. Publikasi: 06130.2007. Katalog: 8201018. Penertbit CV. NASIONAL INDAH. https://www.bps.go.id
Djaeni, M., Agusniar, A., Setyani, D., \& Hargono. (2011). Pengeringan Jagung dengan Metode Mixed Adsorption Drying Menggunakan Zeolite pada Unggun Terfluidisasi. Prosiding Seminar Nasional Sains dan Teknologi ke-2. Fakultas Teknik Universitas Wahid Hasyim Semarang.

Djaeni, M., \& Perdanianti, A. M., (2019). The Study Explores the Effect of Onion (allium cepa l.) Drying using Hot Air Dehumidified by Activated Carbon, Silica Gel and Zeolit. The $3^{\text {rd }}$ International Conference of Chemical and Material Engineering. IOP Conf.Series: Journal of Physiscs: Conf. Series, 1295 (2019), 012025 . doi: 10.1088/17426596/1295/1/012025.

Djaeni, M., Sasongko, S. B., \& Van Boxtel, A. J. B. (2013). Enhacement of Energy Efficiency and Food Product Quality Using Adsorption Dryer with Zeolite. Int.Journal of Renewable Energy Development (IJRED), 2(2), 81-86. doi: 10.14710/ijred.2.2.81-86.

Geankoplis, C. J. (1993). Transport Process and Unit Operations. Edition 3rd. Prentice-Hall International, Inc.

Hancioglu, E, Hepbasli, A., Icier, F., Erbay, Z., \& Colak, N. (2010). Performance Investigation of Drying of Parsley in a Tray Dryer System. Int. J. Exergy, 7(2), 193-210. doi: 10.1504/ijex.2010.031240.

Lewis, W. (1921). The Rate of Drying of Solid Materials. Journal Ind.Eng.Chem. 65(1), 427-431. doi: 10.1021/ie50137a021

Misha, R, Mat, S., Ruslan, M. H., Sopian, K., \& Salleh, E. (2013) Review on a Tray Dryer System for Agricultural Products. World Applied Sciences Journal, 22(3), 424-433. doi: 105829/idosi.wasj.2013.22.03.343. 
Mitra, J., Shrivastava, S. L., \& Rao, P. S. (2012). Onion Dehydration: a review. Journal Food Sci. Technol., 49, 267-277. doi: 10.1007/s13197011-0369-1.

Mota, C. L, Luciano, C., Dias, M. J., Barroca, \& Guine R. P. V., (2010). Convective Drying of Onion: Kinetic and Nutritional Evaluation. Food Bioprod. Process., 8(2-3), 115-123. doi: 10.1016/j.fbp.2009.09.004.

Nugraha, S., Adiandri, R.S., \& Yulianingsih. (2011). Pelayuan dan Pengeringan Bawang Merah Menggunakan Instore Drying untuk Mempertahankan Mutu dan Mengurangi Tingkat Kerusakan. Jurnal Pasca Panen, 8(2),72-81.

Pradana, G. B., Prabowo, K. B., Hastuti, R. P., Djaeni, M., \& Prasetyaningrum, A., (2019). Seaweed Drying Process Using Tray Dryer with Dehumidified Air System to Increase Efficiency of Energy and Quality Product. Internasional Conference on Food Science \& Technology.Earth and Enviromental Science, 292 (2019).012070. doi: 10.1088/17551315/292/1/012070.

Rodrigues, A., Fogliano, V., Graziani G., Mendes, S., Vale, A. \& Goncalves, C. (2003). Nutrition Value of Onion Regional Varieties in Northwest Portugal. EJEAFChe, 2(4), 519-524.

Santoso, D., Muhidong, D., \& Mursalim. (2018). Model Matematis Pengeringan Lapisan Tipis Biji Kopi Arabika (Coffeae arabica) dan Biji Kopi Robusta (Coffeae cannephora). Jurnal Teknologi Pertanian Andalas, 22(1), 86-95. doi: 10.25077/jtpa.22.1.86-95.2018
Sasongko, S. B., Hadiyanto, H., Djaeni, M., Perdanianti A. M., \& Utari F. B. (2020). Effect of Drying Temperature and Relative Humidity on the Quality of Dried Onion Slice. Heliyon, 6(7), e04338. doi: 10.1016/j.heliyon.2020.e04338.

Traub, D. A., (2002). The Drying Curve Part 1. https://www.processheating.com/articles/86586-thedrying-curve-part-1 (diakses pada 12 Juli 2019). 